\title{
TOTAL QUALITY MANAGEMENT PADA BALAI LATIHAN PENDIDIKAN TEKNIK GMIM KAATEN TOMOHON DI KOTA TOMOHON
}

\author{
Korompis Meggi Leddy Meylan \\ Celcius Talumingan \\ Leonardus R. Rengkung
}

\begin{abstract}
The aim of this research is to know the application of Total Quality Management at Technical Training Center (BLPT) GMIM KAATEN TOMOHON. The study was conducted from February to April 2017. The data used in this study are primarily qualitative data relating to the measurement of Total Quality Mananagement, consists of Customer Focus data, Obsession with quality, Long-term commitment, Team Work, Education and training. Data collection uses a list of questions to be asked directly to the management and employees and Consumers. The results of the study and discussion on the application of Total Quality Management to the customers and to the leadership and employees of BLPT GMIM Kaaten Tomohon indicate that included in the highly satisfied category are Obsessions on Quality, Long Term Commitment, Teamwork, and for Education and Training. While the included in the category of satisfaction is Focus on Customers.
\end{abstract}

Keywords: quality, management, technical training center, GMIM Kaaten, Tomohon City

\begin{abstract}
ABSTRAK
Penelitian bertujuan untuk mengetahui penerapan Total Quality Management pada Balai Latihan Pendidikan Teknik (BLPT) GMIM KAATEN TOMOHON. Penelitian dilaksanakan pada bulan Februari sampai April 2017. Data yang digunakan dalam ini adalah data primer yang bersifat kualitatif, yang berkaitan dengan pengukuran Total Quality Mananagement, meliputi fokus pada pelanggan, obsesi terhadap kualitas, komitmen jangka panjang, kerja sama tim (team work), pendidikan dan pelatihan. Pengumpulan data menggunakan daftar pertanyaan yang ditanyakan langsung kepada pimpinan dan karyawan serta konsumen sebagai responden. Hasil penelitian dan pembahasan mengenai penerapan Total Quality Management terhadap pelanggan dan terhadap pimpinan dan karyawan di BLPT GMIM Kaaten Tomohon menunjukkan bahwa yang termasuk pada kategori sangat puas adalah Obsesi terhadap Kualitas, Komitmen Jangka Panjang, Kerjasama Tim (Teamwork), dan untuk Pendidikan dan Pelatihan. Sedangkan yang termasuk pada kategori puas adalah Fokus pada Pelanggan.
\end{abstract}

Kata kunci: kualitas, management, Balai Latihan Pendidikan Teknik, GMIM Kaaten, Kota Tomohon 


\section{PENDAHULUAN}

\section{Latar belakang}

Organisasi merupakan kumpulan sumberdaya manusia (human rersources) maupun sumberdaya lainnnya (non-human resources) dengan bangunan sistem yang memiliki tujuan. Secara umum organisasi terbagi dalam dua kelompok besar yaitu organisasi yang berorientasi bisnis, yang sering disebut private organization dan yang tidak berorientasi bisnis yang disebut sebagai public organization. Metcalfe (2005) menyatakan bahwa organisasi bisnis merupakan organisasi yang melakukan aktivitas ekonomi dengan tujuan untuk menghasilkan keuntungan. Organisasi bisnis yang baik diperlukan tujuan yaitu merupakan kebutuhan yang ingin dipenuhi dalam jangka waktu tertentu contohnya produktifitas, sumber daya fisik, inovasi dan terutama untuk mencari keuntungan (Profit). Seiring dengan meningkatnya persaingan yang semakin cepat, dengan diikuti perubahan selera konsumen, kemajuan teknologi, serta perubahan sosial ekonomi memunculkan tantangan-tantangan dan peluang dalam bisnis. Beragam jenis dan usaha bisnis memang mengharapkan supaya mendapatkan keuntungan perusahaan harus dapat memanfaatkan kemampuan yang dimiliki agar dapat memenangkan persaingan dan memperoleh profit perusahaan. Namun yang tidak bisa mengelolanya dengan baik bisa mengalami kerugian semaksimal mungkin yang merupakan salah satu tujuan didirikannya. Kepemimpinan sumber daya manusia yang baik diperlukan dalam melakukan organisasi bisnis supaya usaha yang dilakukan bisa berjalan dengan baik dan bisa lebih berkembang terlebih mampu memenuhi kebutuhan pelanggan atau lebih berkualitas.Kualitas merupakan kunci keunggulan untuk bersaing yaitu kemampuan suatu perusahaan untuk mendapatkan keunggulan yang ada dipasar.

Menurut Gasperz dalam Wilson (2009) menyatakan bahwa kualitas adalah totalitas dari fitur-fitur dan karakteristik - karakteristik yang dimiliki oleh produk yang memuaskan kebutuhan konsumen. Sedangkan menurut Kotler dalam Wilson (2009) berpendapat bahwa kualitas adalah seluruh ciri serta sifat suatu produk atau pelayanan berpengaruh pada kemampuan untuk memuaskan kebutuhan yang dinyatakan atau yang tersirat. Manajemen kualitas sangat penting bagi suatu perusahaan untuk memenuhi selera konsumen dalam perkembangan jaman. Manajemen kualitas dapat diterapkan dalam barang dan jasa yang ditekankan dalam peningkatan sistem kualitas. Untuk menciptakan produk yang memiliki kualitas secara total yaitu disebut Total Quality Management. Menurut Gaspersz (2001) Total Quality Management merupakan suatu konsep manajemen yang merespon tentang pendekatan dalam menjalankan suatu usaha yang mencoba untuk memaksimalkan daya saing organisasi melalui perbaikan terus menerus atas produk, jasa, tenaga kerja, serta prosesnya. Sedangkan menurut Mulyadi (2005) Total Quality Management didefinisikan sebagai suatu cara meningkatkan performansi secara terus menerus pada setiap evel operasi atau proses dalam setiap area fungsional dari suatu organisasi dengan menggunakan semua sumber daya manusia dan model tersedia. Total Quality Management merupakan sistem yang berfokus atau bertujuan untuk meningkatkan secara berkelanjutan terus menerus.

Menurut Chase, et al. (2005) adapun prinsip-prinsip Total Quality Management yaitu produk, proses, organisasi, pemimpin, komitmen serta menegaskan bahwa Total Quality Management merupakan paradigma baru dalam menjalankan bisnis yang berupaya memaksimumkan daya saing perusahaan melalui fokus pada kepuasan konsumen, keterlibatan seluruh karyawan, dan perbaikan secara berkesinambungan atas kualitas produk, jasa, manusia, proses dan lingkungan perusahaan. Kinerja Perusahaan yang baik merupakan salah satu indikator agar Perusahaan bisa berkembang. Perkembangan Perusahaan yang baik akan meningkatkan daya saing perusahaan khususnya dalam persaingan bisnis. Dalam hal ini Balai Latihan Pendidikan Teknik (BLPT) GMIM KAATEN TOMOHON DI KOTA TOMOHON merupakan sarana yang memproduksi Rumah Panggung/ Meubel dan Soufenir yang terbuat dari Kayu kelapa. Dunia Industri untuk meningkatkan penjualan dapat 
terjadi jika perusahaan mengimplementasikan secara benar Total Quality Management di seluruh aspek pada operasional perusahaan. Dibutuhkan secara terus-menerus pada semua bagian-bagian untuk diimplementasikan untuk melengkapi pelaksanaan terbaik perusahaan untuk mendapatkan kualitas produk dan pelayanan seperti yang dibutuhkan, dan hal tersebut nantinya akan berimbas kepada penjualan perusahaan.

\section{Perumusan Masalah}

Berdasarkan latar belakang yang telah dikemukakan, dapat dilihat bahwa masalah dalam penelitian ini adalah apakah Balai Latihan Pendidikan Teknik (BLPT) GMIM KAATEN TOMOHON sudah menerapkan prinsip - prinsip Total Quality Management (TQM) dalam produksi?

\section{Tujuan}

Tujuan dari penelitian ini yaitu untuk mengetahui penerapan Total Quality Management pada Balai Latihan Pendidikan Teknik (BLPT) GMIM KAATEN TOMOHON.

\section{Manfaat}

Untuk memberikan informasi yang lebih jelas mengenai Total Quality Management yang ada bagi pengusaha dalam mengelola Balai Latihan Pendidikan Teknik (BLPT) GMIM KAATEN TOMOHON.

\section{METODE PENELITIAN}

\section{Waktu dan Tempat Penelitian}

Penelitian dilaksanakan pada bulan Februari sampai April 2017 dengan lokasi penelitian bertempat pada Balai Latihan Pendidikan Tomohon (BLPT) GMIM KAATEN TOMOHON yang bertempat di PPWG Matani I, Jln Raya Tomohon-Tondano.

\section{Metode Pengumpulan Data}

Data yang digunakan dalam ini adalah data primer yang bersifat kualitatif, yang berkaitan dengan pengukuran Total Quality Mananagement, seperti data tentang Fokus pada pelanggan, Obsesi terhadap kualitas, Komitmen jangka panjang, Kerja sama tim (team work), Pendidikan dan pelatihan. Data tentang Fokus pada Pelanggan akan ditanyakan pada pelanggan. Dan Data tentang Obsesi terhadap kualitas, Komitmen jangka panjang, Kerja sama tim (team work), Pendidikan dan pelatihan akan ditanyakan pada pimpinan dan karyawan. Pengumpulan data menggunakan daftar pertanyaan yang akan ditanyakan langsung kepada pimpinan dan karyawan serta Konsumen. Data kualitatif tesebut akan dikuantifikasi dengan menggunakan Skala Likert dengan jenjang 1 sampai 5 yaitu:

1 = Sangat Tidak Setuju

2 = Tidak Setuju

$3=$ Netral

4 = Setuju

5 = Sangat Setuju

\section{Metode Pengambilan Sampel}

Dalam penelitian ini terdapat dua populasi yaitu Pelanggan dan Pimpinan/Karyawan Balai Latihan Pendidikan Teknik (BLPT) GMIM KAATEN TOMOHON. Teknik pengambilan sampel baik Pelanggan dan Pimpinan/Karyawan akan diambil secara Accidental sampling. Accidential sampling adalah bagian dari populasi yang memiliki ciri-ciri yang dimiliki oleh populasinya. Teknik penarikan sampel yang digunakan dalam penelitian ini yaitu accidental sampling yaitu pengambilan sampel secara kebetulan saja yang bertemu dengan peneliti dan dapat dijadikan sampel. Pertanyaan untuk Pelanggan sebanyak 30 responden dan untuk Pimpinan dan Karyawan di BLPT GMIM Kaaten Tomohon sebanyak 30 responden.

\section{Konsep Pengukuran Variabel}

Karakteristik Responden, mencakup :

a) Jenis kelamin : ( Laki - laki / perempuan )

b) Umur : Usia Responden (Tahun)

c) Pekerjaan : Profesi Responden

d) Tingkat pendidikan: Pendidikan terakhir responden

Variabel yang diukur dalam penelitian ini adalah yang berhubungan dengan unsur - unsur Total Quality Management, dimana dikembangkan dari 10 tulisan tentang komponen TQM, karena menyesuaikan dengan kondisi perusahaan hanya diambil 5 komponen yang penting, yaitu:

1. Fokus pada pelanggan :

- Perhatian perusahaan terhadap pelanggan.

- Pelayanan yang baik terhadap pelanggan 
- Kecepatan menanggapi pelanggan.

2. Obsesi terhadap kualitas :

- Peningkatan kualitas produk terus menerus.

- Memberikan kualitas produk yang baik.

3. Komitmen jangka panjang

- Perusahaan memiliki perencanaan.

- Karyawan selalu memenuhi keinginan pelanggan.

4. Kerja sama Tim (Teamwork) :

- Penciptaan suasana kerja yang baik.

- Adanya kerjasama antara pimpinan dan karyawan.

- Adanya kerjasama antara karyawan.

5. Pendidikan dan pelatihan:

- Adanya pelatihan dan pendidikan bagi karyawan.

- Membuat training khusus staf.

\section{Metode Analisis Data}

Analisis data dalam penelitian ini adalah deskriptif, yaitu dengan cara menjelaskan semua variabel pengukuran yang berkaitan dengan Total Quality Management. Untuk mengukur sikap akan disusun 3 pertanyaan untuk konsumen dan 9 pertanyaan untuk pimpinan dan karyawan. Jumlah sampel baik Pelanggan dan Pimpinan/Karyawan akan diambil secara Accidental sampling masingmasing sebanyak 30 responden untuk pelanggan dan 30 responden untuk pimpinan dan karyawan. Setiap jawaban dihubungkan dengan bentuk pernyataan atau dukungan sikap yang diungkapkan dengan kata - kata berikut menurut Tangkulung (2015):

1 = Sangat Tidak Setuju

2 = Tidak Setuju

3 = Netral

4 = Setuju

5 = Sangat Setuju

Dengan cara perhitungan skor masing masing pertanyaan khusus Konsumen dan pertanyaan untuk pimpinan serta karyawan : Jumlah skor tiap kriteria = Capaian skor $\mathrm{X}$ Jumlah Responden Untuk :

$\mathrm{S} 1=1 \times 30=30$

$\mathrm{S} 2=2 \times 30=60$

$\mathrm{S} 3=3 \times 30=90$

$\mathrm{S} 4=4 \times 30=120$

$\mathrm{S} 5=5 \times 30=150$
Jumlah skor ideal untuk setiap pertanyaan ( skor tertinggi $)=150$

Jumlah skor terendah $=30$

Dengan interpretasi nilai:

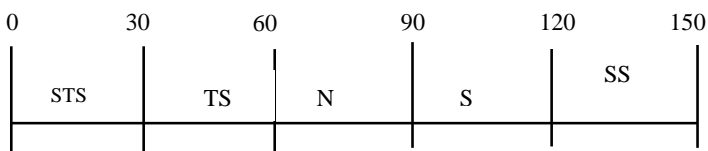

Cara perhitungan skor keseluruhan untuk mengetahui unsur - unsur Total Quality Management : Jumlah skor seluruh kriteria = Capaian jumlah skor X Jumlah Responden X Instrumen pertanyaan

Untuk pertanyaan terhadap pelanggan

$\mathrm{S} 1=1 \times 30 \times 3=90$

$\mathrm{S} 2=2 \times 30 \times 3=180$

$\mathrm{S} 3=3 \times 30 \times 3=270$

$\mathrm{S} 4=4 \times 30 \times 3=360$

$\mathrm{S} 5=5 \times 30 \times 3=450$

Jumlah skor ideal untuk keseluruhan pernyataan 450 ( tertinggi ) Jumlah skor terendah 90

Dengan interpretasi nilai:

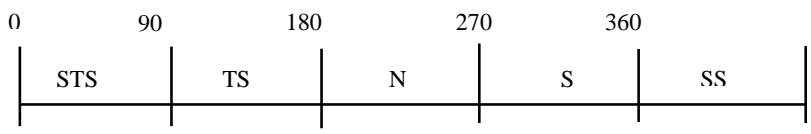

Untuk pertanyaan terhadap Pimpinan dan Karyawan

$\mathrm{S} 1=1 \times 30 \times 9=270$

$\mathrm{S} 2=2 \times 30 \times 9=540$

$\mathrm{S} 3=3 \times 30 \times 9=810$

$\mathrm{S} 4=4 \times 30 \times 9=1080$

$\mathrm{S} 5=5 \times 30 \times 9=1350$

Jumlah skor ideal untuk keseluruhan pernyataan 1350 ( tertinggi )

Jumlah skor terendah 270

Dengan interpretasi nilai:

Analisis data yang digunakan merupakan analisis deskriptif yang dianalisis dengan menggunakan skala pengukuran Likert Scale adalah sebagai berikut :

Tingkat kepuasan responden $=$ $\frac{\text { Jumlah Skor Hasil Pengumpulan Data }}{\text { Jumlah skor ideal (tertinggi) }} \times 100 \%$

Dengan interpretasi nilai:

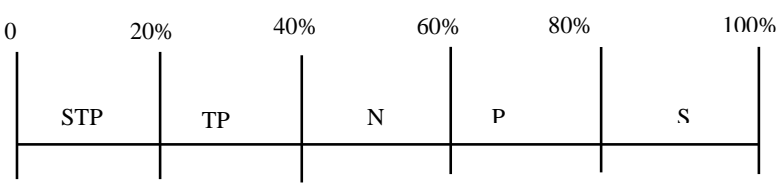


Keterangan Kriteria interpretasi skor unsur- unsur TotaL Quality Management :

Angka $0 \%-20 \%=$ Sangat Tidak Puas

Angka 20\% - 40\% = Tidak Puas

Angka $40 \%-60 \%=$ Netral

Angka $60 \%-80 \%=$ Puas

Angka $80 \%-100 \%=$ Sangat Puas

\section{HASIL DAN PEMBAHASAN}

\section{Deskripsi Balai Latihan Pendidikan Teknik GMIM Kaaten Tomohon}

Balai Latihan Pendidikan Teknik (BLPT) GMIM Kaaten Tomohon merupakan tempat pendidikan dan pelatihan serta tempat memproduksi bahan - bahan alami, dan pemanfaatan pohon kelapa yang sudah tidak produktif lagi untuk bahan bangunan, Mebel dan Souvenir. Balai Latihan Pendidikan Teknik (BLPT) GMIM Kaaten Tomohon diresmikan pada tanggal 5 Februari 1992. Balai Latihan Pendidikan Teknik (BLPT) GMIM Kaaten Tomohon merupakan naungan dari Gereja Masehi Injili di Minahasa. Lokasi Balai Latihan Pendidikan Teknik (BLPT) berada di Matani 1 Jln raya Tomohon - Tondano. Jumlah Karyawan di Balai Latihan Pendidikan Teknik (BLPT) GMIM Kaaten Tomohon ada 40 orang. Yang terbagi atas : Kepala (1 Orang), Bagian Operasional (1 Orang), Bagian Administrasi Keuangan (1 Orang), Bagian Produksi (1 Orang), Bagian Personalia (1 Orang), Bagian Marketing Penjualan (2 Orang), Bagian Persiapan (7 Orang), Bagian Mesin (3 Orang), Bagian Mebel (6 Orang), Bagian Bangunan (4 Orang), Bagian Finishing (6 Orang), Bagian Barang Kecil (3 Orang), Bagian Mekanik (1 Orang), Bagian Pendidikan (1 Orang), Bagian Gudang (1 Orang), Bagian Gudang Mebel (1 Orang).

\section{Karakteristik Responden}

\section{Jenis Kelamin Responden Pelanggan}

Dalam mengkonsumsi suatu produk pada dasarnya tidak terpengaruh pada jenis kelamin dalam artian semua konsumen baik Laki - laki atau perempuan selalu melakukan kegiatan untuk memakai produk untuk memenuhi kebutuhan yang ada. Berikut ini tabel yang menunjukkan Jenis kelamin responden yang memakai produk (Pelanggan) di BLPT GMIM Kaaten Tomohon.

Tabel 1. Jumlah Responden Menurut Jenis Kelamin (Pelanggan)

\begin{tabular}{cccc}
\hline No & $\begin{array}{c}\text { Jenis } \\
\text { Kelamin }\end{array}$ & $\begin{array}{c}\text { Jumlah } \\
\text { (orang) }\end{array}$ & $\begin{array}{c}\text { Presentase } \\
(\boldsymbol{\%})\end{array}$ \\
\hline 1 & Laki - laki & 13 & 43,3 \\
2 & Perempuan & 17 & 56,7 \\
\hline & Jumlah & 30 & 100 \\
\hline
\end{tabular}

Tabel 1 menunjukkan jumlah responden konsumen yang menggunakan atau yang berbelanja produk di BLPT GMIM Kaaten Tomohon berdasarkan Jenis Kelamin. Sebagian besar konsumen yang berbelanja adalah yang berjenis kelamin perempuan dengan jumlah 17 orang $(56,7 \%)$ sedangkan konsumen laki - laki sebanyak 13 Orang $(43,3)$ dari total seluruh responden.

\section{Pimpinan dan Karyawan}

Dalam bekerja di suatu perusahaan pada dasarnya tidak terpengaruh pada jenis kelamin dalam artian semua karyawan baik Laki - laki atau perempuan selalu melakukan kegiatan yang sama untuk memenuhi kebutuhan pelanggan. Berikut ini tabel yang menunjukkan Jenis kelamin responden yang bekerja di BLPT GMIM Kaaten Tomohon.

Tabel 2. Jumlah Responden Menurut Jenis Kelamin (Pimpinan dan Karyawan)

\begin{tabular}{cccc}
\hline No & $\begin{array}{c}\text { Jenis } \\
\text { Kelamin }\end{array}$ & $\begin{array}{c}\text { Jumlah } \\
\text { (orang) }\end{array}$ & $\begin{array}{c}\text { Presentase } \\
(\boldsymbol{\%})\end{array}$ \\
\hline 1 & Laki - laki & 26 & 86,7 \\
2 & Perempuan & 4 & 13,3 \\
\hline & Jumlah & 30 & 100 \\
\hline
\end{tabular}

Tabel 2 menunjukkan jumlah responden Pimpinan dan Karyawan yang bekerja di BLPT GMIM Kaaten Tomohon berdasarkan Jenis Kelamin. Sebagian besar yang berkerja di BLPT GMIM Kaaten Tomohon adalah yang berjenis kelamin Laki - laki dengan jumlah 26 orang $(86,7 \%)$ sedangkan yang perempuan sebanyak 4 Orang $(13,3)$ dari total seluruh responden. 


\section{Umur Responden}

\section{Pelanggan}

Tingkat umur mempengaruhi kemampuan seseorang dalam melakukan aktivitas maupun konsep berpikir khususnya dalam mengkonsumsi suatu produk. Konsumen yang memiliki umur yang lebih muda tentunya memiliki kesukaan atau selera yang berbeda dengan konsumen yang berumur lebih dewasa. Berikut komposisi umur responden dalam penelitian ini.

Tabel 3. Jumlah Responden Berdasarkan Tingkat Umur (Pelanggan)

\begin{tabular}{cccc}
\hline No & $\begin{array}{c}\text { Umur Responden } \\
\text { (Tahun) }\end{array}$ & $\begin{array}{c}\text { Jumlah } \\
\text { (orang) }\end{array}$ & $\begin{array}{c}\text { Presentase } \\
(\boldsymbol{\%})\end{array}$ \\
\hline 1 & $\leq 20$ & - & - \\
2 & $21-30$ & 1 & 3,3 \\
3 & $31-40$ & 11 & 36,7 \\
4 & $41-50$ & 13 & 43,3 \\
5 & $\geq 50$ & 5 & 16,7 \\
\hline & Jumlah & 30 & 100 \\
\hline
\end{tabular}

Tabel 3 menunjukkan bahwa jumlah responden terbanyak berada pada interval 41 50 Tahun yaitu sebanyak 13 Orang $(43,3 \%)$. Sedangkan jumlah konsumen terendah berada pada interval umur 21 - 30 Tahun yaitu 1 orang $(3,3 \%)$.

\section{Pimpinan dan Karyawan}

Tingkat umur juga bisa mempengaruhi kemampuan seseorang dalam berpikir dan melakukan aktivitas yang dilakukan. Pimpinan dan Karyawan di BLPT GMIM Kaaten Tomohon memiliki umur yang berbeda - beda. Berikut Komposisi umur Responden khususnya pimpinan dan Karyawan dalam penelitian ini.

Tabel 4. Jumlah Responden Berdasarkan Tingkat Umur (Pimpinan dan Karyawan)

\begin{tabular}{cccc}
\hline No & $\begin{array}{c}\text { Umur Responden } \\
\text { (tahun) }\end{array}$ & $\begin{array}{c}\text { Jumlah } \\
\text { (orang) }\end{array}$ & $\begin{array}{c}\text { Presentase } \\
(\%)\end{array}$ \\
\hline 1 & $\leq 20$ & - & - \\
2 & $21-30$ & - & - \\
3 & $31-40$ & 4 & 13,3 \\
4 & $41-50$ & 16 & 53,3 \\
5 & $\geq 50$ & 10 & 33,4 \\
\hline & Jumlah & 30 & 100 \\
\hline
\end{tabular}

Tabel 4 menunjukkan bahwa umur responden atau karyawan terbanyak berada pada interval umur 41 - 50 Tahun yaitu sebanyak 16 Orang $(53,3 \%)$. Sedangkan jumlah karyawan terendah berada pada interval umur 31 - 40 Tahun yaitu 4 orang $(13,3 \%)$.

\section{Tingkat Pendidikan}

\section{Pelanggan}

Tingkah laku seseorang sangat dipengaruhi oleh pendidikan yang telah dicapai. Seorang konsumen yang memiliki tingkat pendidikan yang tinggi cenderung akan memilih suatu produk yang berkualitas. Begitu juga dalam mengambil keputusan untuk memilih alternativ pilihan yang hendak dipilih. Berikut ini tabel yang menunjukkan jumlah responden berdasarkan tingkat pendidikan.

\section{Tabel 5. Jumlah Responden Menurut Tingkat Pendidikan (Pelanggan)}

\begin{tabular}{cccc}
\hline No & $\begin{array}{c}\text { Tingkat } \\
\text { Pendidikan }\end{array}$ & $\begin{array}{c}\text { Jumlah } \\
\text { (orang) }\end{array}$ & $\begin{array}{c}\text { Presentase } \\
(\%)\end{array}$ \\
\hline 1 & SD & - & - \\
2 & SMP & 7 & 23,3 \\
3 & SMA & 11 & 36,7 \\
4 & S1 & 12 & 40 \\
5 & S2 & - & - \\
6 & S3 & - & - \\
\hline & Jumlah & 30 & 100 \\
\hline
\end{tabular}

Tabel 5 menunjukkan bahwa tingkat pendidikan responden yang terbanyak yaitu pada tingkat $\mathrm{S} 1$ dimana terdapat 12 orang responden $(40 \%)$. Sedangkan tingkat pendidikan responden yang paling sedikit yaitu tingkat pendidikan SMP dimana terdapat 7 Orang responden $(23,3 \%)$ dari jumlah responden yang ada.

\section{Pimpinan dan Karyawan}

Tingkat atau jenjang pendidikan merupakan tahapan yang ditetapkan berdasarkan perkembangan, tujuan yang akan dicapai, dan kemampuan yang dikembangkan dalam bekerja. Berikut ini tabel yang menunjukkan jumlah responden berdasarkan 
tingkat pendidikan karyawan atau pimpinan yang bekerja di BLPT GMIM Kaaten Tomohon.

\begin{tabular}{|c|c|c|c|}
\hline & $\begin{array}{l}\text { Pendidil } \\
\text { Karyaw }\end{array}$ & & dan \\
\hline No & $\begin{array}{c}\text { Tingkat } \\
\text { Pendidikan }\end{array}$ & $\begin{array}{l}\text { Jumlah } \\
\text { (orang) }\end{array}$ & $\begin{array}{c}\text { Presentase } \\
(\%)\end{array}$ \\
\hline 1 & SD & 2 & 6,7 \\
\hline 2 & SMP & 8 & 26,6 \\
\hline 3 & SMA & 18 & 60 \\
\hline 4 & $\mathrm{~S} 1$ & 2 & 6,7 \\
\hline 5 & S2 & - & - \\
\hline 6 & S3 & - & - \\
\hline & Jumlah & 30 & 100 \\
\hline
\end{tabular}

Tabel 6 menunjukkan bahwa tingkat pendidikan responden yang terbanyak yaitu pada tingkat SMA dimana terdapat 18 Orang responden $(60 \%)$. Sedangkan tingkat pendidikan responden yang paling sedikit yaitu tingkat pendidikan SD terdapat 2 Orang responden $(6,7$ $\%)$ dan $\mathrm{S} 1$ terdapat 2 Orang responden $(6,7 \%)$ dari jumlah responden yang ada.

\section{Pekerjaan Responden}

\section{Pelanggan}

Jenis pekerjaan apapun bisa mempengaruhi cara berpikir seseorang dalam memilih produk yang ada di BLPT GMIM Kaaten Tomohon disitu bisa dilihat barang yang diproduksi memiliki kualitas yang baik untuk dipakai pada saat sekarang. Berikut ini tabel yang menunjukkan jumlah responden berdasarkan Jenis pekerjaan.

Tabel 7. Jumlah Responden Menurut Jenis Pekerjaan (Pelanggan)

\begin{tabular}{|c|c|c|c|}
\hline No & $\begin{array}{c}\text { Jenis } \\
\text { Pekerjaan }\end{array}$ & $\begin{array}{l}\text { Jumlah } \\
\text { (orang) }\end{array}$ & $\begin{array}{c}\text { Presentase } \\
(\%)\end{array}$ \\
\hline 1 & PNS & 9 & 30 \\
\hline 2 & Swasta & 18 & 60 \\
\hline 3 & Wiraswasta & 2 & 6,7 \\
\hline 4 & $\begin{array}{c}\text { Mahasiswa / } \\
\text { Pelajar }\end{array}$ & 1 & 3,3 \\
\hline \multirow[t]{2}{*}{5} & Lainnya & - & - \\
\hline & Jumlah & 30 & 100 \\
\hline
\end{tabular}

Tabel 7 menunjukkan bahwa penelitian ini terdapat 4 kategori jenis pekerjaan dari responden, yaitu PNS, Swasta, Wiraswasta, dan
Mahasiswa/Pelajar. Jenis pekerjaan yang paling terbanyak dari responden yaitu sebanyak 18 orang $(60 \%)$. Sedangkan jenis pekerjaan yang paling sedikit yaitu mahasiswa/pelajar sebanyak 1 orang $(3,3 \%)$ dari keseluruhan jumlah responden.

\section{Pimpinan dan Karyawan}

Karakteristik responden berdasarkan jabatan atau bagian - bagian tugas pekerjaan di BLPT GMIM Kaaten Tomohon. Berikut ini tabel yang menunjukkan jumlah responden berdasarkan Jenis pekerjaan.

Tabel 8. Jumlah Responden Menurut Jenis Pekerjaan (Pimpinan dan karyawan)

\begin{tabular}{clcc}
\hline No & Jenis Pekerjaan & $\begin{array}{c}\text { Jumlah } \\
\text { (orang) }\end{array}$ & $\begin{array}{c}\text { Presentase } \\
(\boldsymbol{\%})\end{array}$ \\
\hline 1 & Bagian Persiapan & 5 & 16,7 \\
2 & Bagian Bangunan & 4 & 13,3 \\
3 & Bagian Mekanik & 2 & 6,7 \\
4 & Bagian Finishing & 4 & 13,3 \\
5 & Bagian Barang & 4 & 13,3 \\
& Kecil & & 6,7 \\
6 & Bagian Staf / & 2 & 16,7 \\
7 & Pimpinan & 5 & 6,7 \\
8 & Bagian Mebel & 2 & 3,3 \\
9 & Bagian Marketing & 1 & 3,3 \\
10 & Bagian Produksi & 1 & 100 \\
\hline
\end{tabular}

Tabel 8 menunjukkan bahwa penelitian ini terdapat 10 Kategori jenis pekerjaan atau Bagian tugas dalam BLPT GMIM Kaaten Tomohon. Jenis pekerjaan atau karyawan terbanyak dari responden yaitu dalam bagian persiapan dan bagian mebel masing - masing terdapat 5 Orang responden (16,7). Sedangkan jenis pekerjaan yang paling sedikit yaitu dalam bagian gudang dan bagian produksi masing - masing terdapat 1 orang $(3,3)$ dari keseluruhan jumlah responden.

\section{Unsur-unsur Total Quality Management (TQM)}

Total Quality Management merupakan suatu pendekatan dalam menjalankan suatu usaha yang mencoba memaksimumkan daya saing organisasi atau perbaikan yang terjadi secara terus menerus atas dasar produk, jasa, manusia, proses, dan lingkungannya. Dan Total Quality Management juga merupakan sistem manajemen untuk meningkatkan kualitas 
menuju pencapaian keunggulan bersaing yang berorientasi untuk memuaskan pelanggan dengan melibatkan seluruh anggota organisasi. Dengan demikian bisa disimpulkan Total Quality Management terdapat 5 komponen yang penting yaitu : Fokus pada pelanggan, Obsesi terhadap kualitas, Komitmen jangka panjang, Kerjasama Tim (Teamwork), Pendidikan dan Pelatihan.

\section{Fokus Pada Pelanggan}

Pembahasan yang akan diuraikan dalam tulisan ini menekankan pada bagaimana upaya perusahaan untuk meningkatkan kepuasan pelanggannya melalui pemberian pelayanan yang prima kepada pelanggannya, perusahaan haruslah terlebih dahulu menekankan visinya untuk berorientasi pada pelanggan, terutama dalam kegiatan pemenuhan kebutuhan dan keinginan para pelanggannya. Begitu juga dalam hal Balai Latihan Pendidikan Teknik (BLPT) GMIM Kaaten Tomohon, tentunya berupaya untuk merancang pelayanan yang terbaik bagi pelanggannya. Setelah memiliki beberapa strategi yang dapat digunakan untuk meningkatkan kepuasan pelanggan, terdapat 3 pernyataan yang diberikan dan telah di jawab oleh konsumen yaitu : Perusahaan punya perhatian terhadap pelanggan, Pelayanan yang baik bagi pelanggan dan Selalu menanggapi dengan cepat keinginan pelanggan.

\section{Rekapitulasi Fokus Pada Pelanggan}

Tabel 9. Rekapitulasi Jumlah Skor Pengambilan Data, Indeks Kepuasan, dan Interpretasi pada Indikator Fokus pada pelanggan

\begin{tabular}{clccc}
\multicolumn{4}{c}{ Indikator Fokus pada pelanggan } \\
No & Pernyataan & $\begin{array}{c}\text { Total } \\
\text { Skor }\end{array}$ & $\begin{array}{c}\text { Indeks } \\
\text { Kepuasan } \\
\text { \% }\end{array}$ & Interpretasi \\
\hline 1 & $\begin{array}{l}\text { Perhatian } \\
\text { terhadap } \\
\text { pelanggan } \\
\text { Pelayanan } \\
\text { yang baik } \\
\text { kepada } \\
\text { pelanggan } \\
\text { Menanggapi } \\
\text { keinginan } \\
\text { pelanggan }\end{array}$ & 114 & 76 & Puas \\
\hline
\end{tabular}

Tabel 9 menunjukkan bahwa terdapat 3 indikator Fokus Pada Pelanggan terhadap sikap dimana Indeks kepuasan tertinggi ada 2 pernyataan yaitu pernyataan 1 sebanyak $76 \%$, sedangkan pernyataan ke 2 yaitu $76 \%$ dan ke 3 mendapat indeks kepuasan $72 \%$

\section{Obsesi Terhadap Kualitas}

Dalam organisasi yang menerapkan Total Quality Management (TQM), konsumen sebagai penentu kualitas. Dengan kualitas yang ditetapkan, organisasi harus terobsesi untuk memenuhi atau melebihi apa yang ditentukan. Hal ini berarti bahwa semua karyawan atau pimpinan di BLPT GMIM Kaaten Tomohon selalu berusaha melaksanakan setiap aspek pekerjaannya. Terdapat 3 pernyataan yang diberikan dan telah dijawab oleh responden yaitu Peningkatan kualitas produk dan Memberikan kualitas produk yang baik.

\section{Rekapitulasi Obsesi Terhadap Kualitas}

Tabel 10. Rekapitulasi Jumlah Skor Pengambilan Data, Indeks Kepuasan, dan Interpretasi pada Indikator Obsesi terhadap kualitas

\begin{tabular}{llccc}
\hline No & Pernyataan & $\begin{array}{c}\text { Total } \\
\text { Skor }\end{array}$ & $\begin{array}{c}\text { Indeks } \\
\text { Kepuasan } \\
\%\end{array}$ & Interpretasi \\
\hline 1 & $\begin{array}{l}\text { Peningkatan } \\
\text { Kualitas } \\
\text { produk di }\end{array}$ & & & \\
BLPT GMIM & & & Sangat \\
& $\begin{array}{l}\text { Kaaten } \\
\text { Tomohon } \\
2\end{array}$ & 136 & 90,7 & Puas \\
$\begin{array}{l}\text { Produk yang } \\
\text { dihasilkan dari }\end{array}$ & & & \\
$\begin{array}{l}\text { BLPT GMIM } \\
\text { Kaaten } \\
\text { Tomohon yaitu } \\
\text { baik digunakan } \\
\text { dan bisa tahan } \\
\text { lama }\end{array}$ & & & Sangat \\
\hline
\end{tabular}

Tabel 10 menunjukkan bahwa terdapat 2 indikator Obsesi terhadap kualitas dimana terdapat sikap Indeks kepuasan tertinggi ada 2 pernyataan yaitu pernyataan 1 sebanyak 90,7 $\%$, sedangkan pernyataan ke 2 yaitu 90,7 \% .

\section{Komitmen Jangka Panjang}

Total Quality Management merupakan suatu paradigma baru dalam melaksanakan bisnis. Oleh karena itu, dibutuhkan budaya perusahaan yang baru pula berupa komitmen jangka panjang sangat penting guna 
mengadakan perubahan budaya agar penerapan Total Quality Management dapat berjalan dengan sukses dan sesuai harapan. Disamping itu terdapat 2 pernyataan yang diberikan dan telah dijawab oleh responden yaitu Perusahaan memiliki perencanaan dan Karyawan selalu memenuhi keinginan pelanggan.

\section{Rekapitulasi Komitmen Jangka Panjang}

Tabel 11. Rekapitulasi Jumlah Skor Pengambilan Data, Indeks Kepuasan, dan Interpretasi pada Komitmen Jangka Panjang

\begin{tabular}{|c|c|c|c|c|}
\hline No & Pernyataan & $\begin{array}{l}\text { Total } \\
\text { Skor }\end{array}$ & $\begin{array}{c}\text { Indeks } \\
\text { Kepuasan } \\
\%\end{array}$ & Interpretas \\
\hline 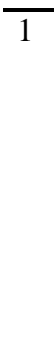 & $\begin{array}{l}\text { BLPT GMIM } \\
\text { Kaaten } \\
\text { Tomohon } \\
\text { memiliki } \\
\text { perencanaan } \\
\text { untuk } \\
\text { mengelola } \\
\text { produk yang } \\
\text { dihasilkan }\end{array}$ & 141 & 94 & Sangat Puas \\
\hline 2 & $\begin{array}{l}\text { BLPT GMIM } \\
\text { Kaaten } \\
\text { Tomohon } \\
\text { selalu } \\
\text { memenuhi } \\
\text { keinginan } \\
\text { pelangan } \\
\text { dengan cepat } \\
\text { dan tepat }\end{array}$ & 137 & 91,3 & Sangat Puas \\
\hline
\end{tabular}

Tabel 11 menunjukkan bahwa terdapat 2 indikator Komitmen jangka panjang dimana terdapat sikap Indeks kepuasan tertinggi ada pernyataan 1 sebanyak $94 \%$, sedangkan pernyataan ke 2 yaitu $91,3 \%$.

\section{Kerjasama Tim (Teamwork)}

Kerjasama Tim juga merupakan sebuah elemen kunci dari Total Quality Management (TQM), yang menjadi alat bagi organisasi dalam mencapai kesuksesan. Dengan menggunakan tim kerja yang akan memperoleh penyelesaian yang cepat dan tepat terhadap semua masalah. Dalam BLPT GMIM Kaaten Tomohon juga memiliki kerjasama yang baik bagi pimpinan dan karyawan contohnya dalam mengalami masalah - masalah yang terjadi dan dengan segera bisa mendapat solusi untuk menyelesaikan masalah yang dihadapi.

\section{Rekapitulasi Kerjasama Tim (Teamwork)}

Tabel 12. Rekapitulasi Jumlah Skor Pengambilan Data, Indeks Kepuasan, dan Interpretasi pada Kerjasama Tim (Team Work)

\begin{tabular}{|c|c|c|c|c|}
\hline No & Pernyataan & $\begin{array}{l}\text { Total } \\
\text { Skor }\end{array}$ & $\begin{array}{c}\text { Indeks } \\
\text { Kepuasan } \\
\%\end{array}$ & Interpretasi \\
\hline 1 & $\begin{array}{l}\text { Selalu tercipta } \\
\text { suasana kerja } \\
\text { yang baik } \\
\text { antara pimpinan } \\
\text { dan karyawan } \\
\text { BLPT GMIM } \\
\text { Kaaten } \\
\text { Tomohon }\end{array}$ & 135 & 90 & $\begin{array}{c}\text { Sangat } \\
\text { Puas }\end{array}$ \\
\hline 2 & $\begin{array}{l}\text { Memiliki } \\
\text { dukungan dari } \\
\text { atasan atau } \\
\text { pimpinan BLPT } \\
\text { GMIM Kaaten } \\
\text { Tomohon }\end{array}$ & 134 & 89,3 & $\begin{array}{c}\text { Sangat } \\
\text { Puas }\end{array}$ \\
\hline 3 & $\begin{array}{l}\text { Memiliki } \\
\text { kerjasama yang } \\
\text { baik antar } \\
\text { karyawan }\end{array}$ & 139 & 92,7 & $\begin{array}{c}\text { Sangat } \\
\text { Puas }\end{array}$ \\
\hline
\end{tabular}

Tabel 12 menunjukkan bahwa terdapat 3 indikator Kerjasama Tim (Team Work) dimana terdapat sikap Indeks kepuasan tertinggi ada pernyataan 1 sebanyak $92,7 \%$, sedangkan pernyataan ke 2 mendapat indeks sebanyak $90 \%$ dan pernyataan ke 3 sebanyak $89,3 \%$.

\section{Pendidikan Dan Pelatihan}

Pendidikan dan pelatihan sangatlah penting artinya karyawan dan pimpinan perusahaan agar bisa menjadi lebih produktif. Dalam hal ini yang terjadi di BLPT GMIM Kaaten Tomohon yaitu Pelatihan yang biasanya dibutuhkan adalah pimpinan dan karyawan agar bisa mendukung tentang penerapan Total Quality Management (TQM) antara lain : Kemampuan interpersonal, kecakapan, bekerjasama dalam tim, dalam menyelesaikan masalah, pengambil keputusan dan mempunyai ketrampilan. Untuk Pimpinan atau Staf harus lebih bertanggung jawab dalam menerapkan Total Quality Management (TQM) kepada semua bawahannya. Pada saat penciptaan dan pembentukan Total Quality Management (TQM), para karyawan dan pimpinan hendaknya segera dilatih agar menjadi karyawan yang efektif bagi perusahaan. 


\section{Rekapitulasi Pendidikan dan Pelatihan}

Tabel 13. Rekapitulasi Jumlah, Skor Pengambilan Data, Indeks Kepuasan, dan Interpretasi tentang Pendidikan dan Pelatihan

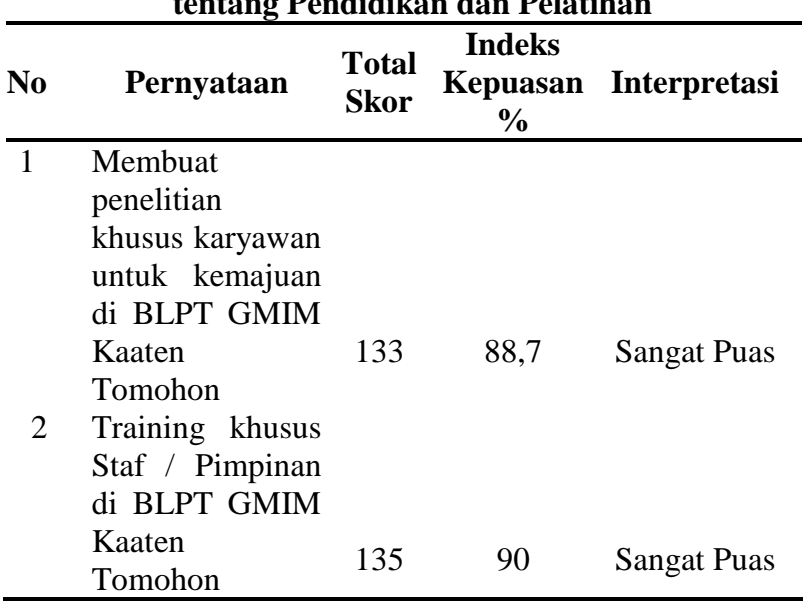

Rekapitulasi Indeks Persepsi Kepuasan pada Masing - masing Indikator dan Interpretasi hasil khusus Pelanggan

Penelitian ini mengukur tentang unsur-unsur yang menjalankan dengan benar Total Quality Management yang diterapkan dan mengambil 3 indikator sebagai tolak ukur dalam penelitian ini yaitu Fokus Pada Pelanggan yang telah di tanyakan khusus untuk konsumen di BLPT GMIM Kaaten Tomohon.

Tabel 14. Rekapitulasi Total Skor, Indeks Kepuasan dan Interpretasi Nilai

\begin{tabular}{llccc}
\hline No & Pernyataan & $\begin{array}{c}\text { Total } \\
\text { Skor }\end{array}$ & $\begin{array}{c}\text { Indeks } \\
\text { Kepuasan } \\
\%\end{array}$ & Interpretasi \\
\hline 1 & $\begin{array}{l}\text { Perhatian } \\
\text { terhadap } \\
\text { pelanggan } \\
\text { Memberikan } \\
\text { pelayanan yang } \\
\text { baik bagi } \\
\text { pelanggan }\end{array}$ & 114 & $76 \%$ & Puas \\
3 & 114 & $76 \%$ & Puas \\
$\begin{array}{l}\text { Menanggapi } \\
\text { keinginan } \\
\text { pelanggan }\end{array}$ & 108 & $72 \%$ & Puas \\
\hline
\end{tabular}

JUntuk mengetahui letak kepuasan pelanggan terdapat Fokus Pada Pelanggan maka perlu dihitung jumlah keseluruhan skor pada setiap kriterium, dimana sesuai dengan hasil penelitian ini skor mencapai 336. Pada penelitian ini jumlah skor ideal (skor tertinggi) yaitu 450 (tinggi) dan jumlah skor terendah yaitu 90 (rendah). Berdasarkan data yang dihimpun dari 3 Instrumen pernyataan yang diajukan kepada 30 responden maka diperoleh total 450 , dengan letak indeks ditentukan berdasarkan skala likert.

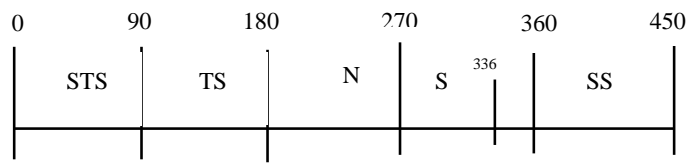

Berdasarkan skala diatas, dapat dilihat dari dapat dilihat bahwa kepuasan konsumen terhadap fokus pada pelanggan terletak pada daerah setuju. Secara presentase, angka indeks, persepsi konsumen terhadap Fokus pada pelanggan yang dihasilkan oleh BLPT GMIM Kaaten Tomohon.

Tingkat kepuasan pelanggan $=\frac{\text { Jumlah Skor Hasil Pengumpulan Data }}{\text { Jumlah skor ideal (tertinggi) }} \times 100 \%$

Tingkat kepuasan pelanggan $=\frac{336}{450} \times 100 \%=74,7 \%$ Dengan interpretasi nilai :

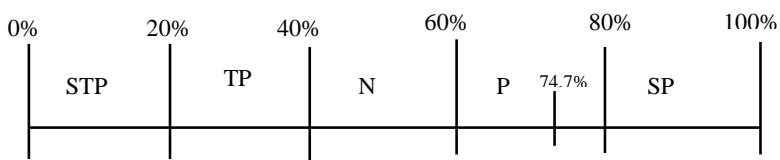

Berdasakan hasil analisis menggunakan skala likert, maka dapat diketahui bahwa angka indeks persepsi konsumen terhadap Total Quality Management didalamnya Fokus Pada Pelanggan di BLPT GMIM Kaaten Tomohon berada pada titik 74,7 dan tergolong Puas. Setiap konsumen memiliki sikap, tingakah laku, motif, pengalaman masa lalu dan harapan yang berbeda beda dalam mengkonsumsi produk yang dihasilkan oleh Balai Latihan Pendidikan Teknik. Dari hasil wawancara kepada konsumen menunjukkan bahwa dalam membeli produk harus memilih produk yang dihasilkan itu dengan baik. Artinya pelanggan di BLPT GMIM Kaaten Tomohon harus menyadari akan hasil yang diproduksi memiliki keunggulan tersendiri. Namun ada beberapa alasan yang menghambat konsumen dalam membeli produk di BLPT GMIM Kaaten Tomohon yaitu :

- Harga produk yang dihasilkan oleh BLPT GMIM Kaaten Tomohon cenderung lebih mahal dibandingkan dengan produk yang dihasilkan oleh perusahaan lainnya, sehingga pelanggan lainnya lebih memilih produk yang lebih murah meskipun sebagian besar konsumen merasa bahwa harga produk di BLPT GMIM Kaaten Tomohon masih bisa lebih dijangkau.

- Lokasi yang jauh dari jalan raya atau keramaian dan tempatnya yang kurang strategis sehingga bisa mmbuat konsumen kurang menjangkau lokasi BLPT GMIM Kaaten Tomohon. 
Tabel 15. Rekapitulasi Total Skor, Indeks Kepuasan dan Interpretasi Nilai

\begin{tabular}{clccc}
\hline $\mathbf{N}$ & \multicolumn{1}{c}{ Pernyataan } & Total Skor & Indeks Kepuasan \% & Interpretasi \\
\hline 1 & Peningkatan kualitas produk & 136 & 90,7 & Sangat Puas \\
2 & Produk yang sangat baik untuk dilihat, rapih, dan tidak & 135 & 90 & Sangat Puas \\
& mudah rusak & 141 & $94 \%$ & Sangat Puas \\
3 & Punya perencanaan untuk mengelola hasil produk & 137 & 91,3 & Sangat Puas \\
4 & Memenuhi apa yang menjadi keinginan dari pelanggan & 135 & $90 \%$ & Sangat Puas \\
5 & Tercipta suasana kerja yang baik bagi pimpinan dan & 134 & 89,3 & Sangat Puas \\
& karyawan yang bekerja & 139 & 92,7 & Sangat Puas \\
7 & Memiliki dukungan dari pimpinan untuk karyawan & Punya kerjasama yang baik antar karyawan & 88,7 & Sangat Puas \\
8 & Membuat penelitian khusus karyawan untuk kemajuan BLPT & 133 & $90 \%$ & Sangat Puas \\
\hline
\end{tabular}

\section{Rekapitulasi Indeks Persepsi Kepuasan pada Masing - masing Indikator dan Interpretasi hasil khusus Pimpinan dan Karyawa}

Penelitian ini mengukur tentang unsurunsur yang menjalankan dengan benar Total Quality Management yang diterapkan dan mengambil 9 indikator sebagai tolak ukur dalam penelitian ini, dimana masing - masing terbagi dalam 4 (Empat) bagian yaitu Obsesi terhadap kualitas, Komitmen jangka panjang, Kerjasama Tim (Team Work), Pendidikan dan Pelatihan. Pertanyaan ini dibuat untuk menanyakan khusus Pimpinan dan Karyawan di BLPT GMIM Kaaten Tomohon. Tabel 15 menunjukkan bahwa unsurunsur yang menjalankan dengan benar Total Quality Management yang diterapkan dan mengambil 9 indikator sebagai tolak ukur dalam penelitian ini, dimana masing - masing terbagi dalam 4 (Empat) bagian yaitu Obsesi terhadap kualitas, Komitmen jangka panjang, Kerjasama Tim (Team Work), Pendidikan dan Pelatihan. Maka perlu dihitung jumlah keseluruhan skor pada setiap kriterium, dimana sesuai dengan hasil penelitian ini skor mencapai 1225. Pada penelitian ini jumlah skor ideal (skor tertinggi) yaitu 1350 (tinggi) dan jumlah skor terendah 270 (rendah). Berdasarkan data yang dihimpun dari 9 instrumen pernyataan yang diajukan kepada 30 responden maka diperoleh total 1350, dengan letak indeks ditentukan berdasarkan Skala Likert.

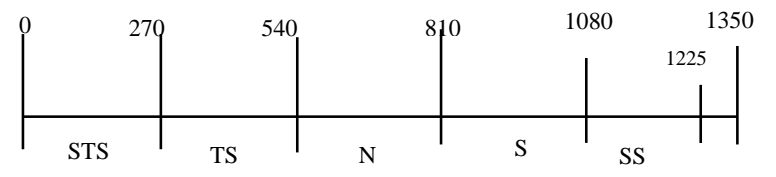

Berdasarkan skala diatas, secara kontinum dapat dilihat bahwa kepuasan responden terhadap Total Quality Management terletak pada daerah sangat setuju. Secara presentase, angka indeks persepsi kepuasan responden terdapat Obsesi terhadap kualitas, Komitmen jangka panjang, Kerjasama Tim (Team Work), Pendidikan dan Pelatihan yang dihasilkan oleh BLPT GMIM Kaaten Tomohon terletak pada:

Tingkat kepuasan responden $=\frac{\text { Jumlah Skor Hasil Pengumpulan Data }}{\text { Jumlah skor ideal (tertinggi) }} \times 100 \%$

Tingkat kepuasan responden $=\frac{1225}{1350} \times 100 \%=90,7 \%$

Dengan interpretasi nilai:

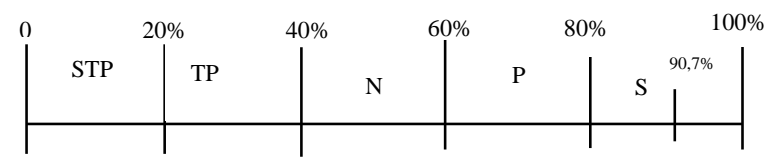

Berdasarkan hasil analisis menggunakan skala likert, maka dapat diketahui bahwa angka indeks persepsi kepuasan responden terhadap unsur Total Quality Management pada BLPT GMIM Kaaten Tomohon berada pada titik 90,7 \% dan tergolong sangat puas. Setiap karyawan memiliki sikap, pengalaman yang berbeda dalam bekerja di BLPT GMIM Kaaten Tomohon. Dari hasil wawancara kepada karyawan dan pimpinan di BLPT GMIM Kaaten Tomohon mereka mampu memberikan perhatian, pelayanan yang baik bagi pelanggan. Hasil penelitian diperoleh bahwa secara keseluruhan persepsi kepuasan responden terhadap Total Quality Management adalah sangat puas, artinya pimpinan dan karyawan di BLPT GMIM Kaaten Tomohon harus menerapkan secara benar Total Quality Management agar perusahaan bisa lebih berkembang dan produk yang dihasilkan bisa berkualitas. 


\section{KESIMPULAN DAN SARAN}

\section{Kesimpulan}

Berdasarkan hasil penelitian dan pembahasan mengenai penerapan Total Quality Management terhadap pelanggan dan terhadap pimpinan dan karyawan di BLPT GMIM Kaaten Tomohon menunjukkan bahwa Fokus Pada Pelanggan berada pada Kategori Puas, Obsesi terhadap Kualitas berada dalam Kategori Sangat Puas, Komitmen Jangka Panjang dalam kategori Sangat Puas, Kerjasama Tim (Teamwork) dalam kategori Sangat Puas, dan untuk Pendidikan dan Pelatihan juga berada dalam kategori Sangat Puas. Cukup baiknya variabel Total Quality Management (TQM) Dalam peningkatan kualitas dan proses memproduksi barang yang ada di BLPT GMIM Kaaten Tomohon. Berdasarkan pengujian diatas variabel Total Quality Management (TQM) berpengaruh terhadap kinerja perusahaan berupa perusahaan mampu menjawab keinginan dari pelanggan dengan baik.

\section{Saran}

Berdasarkan penelitian dan kesimpulan di atas, untuk meningkatkan kualitas produk yang dihasilkan di BLPT GMIM Kaaten Tomohon, disamping itu BLPT GMIM Kaaten Tomohon harus memperhatikan keseluruhan variabel Total Quality Management diantaranya, Fokus pada pelanggan, Obsesi terhadap kualitas, Komitmen jangka panjang, Kerja sama Tim (Teamwork), Pendidikan dan pelatihan. Selain itu BLPT GMIM Kaaten Tomohon juga harus memperhatikan harga dalam menjual produk sehingga harganya tidak terlalu mahal dan konsumen masih bisa menjangkau harga jual di BLPT GMIM Kaaten Tomohon. Dengan sendirinya terjadi peningkatan konsumen di BLPT GMIM Kaaten Tomohon.

\section{DAFTAR PUSTAKA}

Chase et al. 2005. Praktik Total Quality Management \& Pengaruh terhadap kinerja karyawan. Jurnal Manajemen dan Kewirausahaan Vol 12. No 2 185-194
Chairany \& Lestari. 2011. Pengaruh Total Quality Management terhadap kinerja perusahaan melalui kepemimpinan dan perilaku produktif karyawan. Jurusan mesin Fakultas Teknik Universitas Hasanuddin Makassar

Gasperz. 2001. Penerapan Total Quality Management dalam perusahaan kiat bisnis Vol 5. No 1 Desember 2012

Goetsch, Davis, \& Tjiptono. 2003. Karakteristik Total Quality Management dalam mempengaruhi kinerja manajerial pada PT. X. Skripsi Fakultas Ekonomi Universitas Muhammadya Sidoarjo

Metcalfe. 2005. Mengelola suatu perubahan dalam organisasi. Jurnal Ilmu Manajemen Vol 3. No 1 Tahun 2007

Raymond Mcleod. 2001. Sitem Informasi Manajemen. Jilid 1. Jakarta : Prenhalindo

Rorong. 2012. Hubungan antara management dengan Organisasi. Fakultas Ilmu Sosial Politik UNSRAT

Tangkulung. 2015. Analisis Kepuasan Konsumen terhadap Atribut sayuran organik di Hypermart Manado. Skripsi Program Studi Agribisnis Fakultas Pertanian

Wilson. 2009. Pengembangan atribut Jasa. Skripsi Fakultas Ekonomi Universitas Indonesia

Yuniawati. 2003. Pengaruh interaksi antara TQM dengan sistem pengukuran kinerja dan sistem penghargaan terhadap kinerja manajerial PT. Telkom Divre Surabaya. Skripsi Fakultas Ekonomi Universitas Airlangga 